\title{
Location-Based Information Berbasis QR Code Untuk Tourism
}

\author{
Vicky S. Gunawan $^{(1)}$, Alicia A. E. Sinsuw ${ }^{(2)}$, Alwin M. Sambul ${ }^{(3)}$ \\ ${ }^{(1)}$ Mahasiswa, ${ }^{(2)}$ Pembimbing $1,{ }^{(3)}$ Pembimbing 2 \\ Jurusan Teknik Elektro, Program Studi Informatika, Fakultas Teknik, UNSRAT, Manado-95115, Email: \\ 120216151@student.unsrat.ac.id, Alicia.sinsuw@unsrat.ac.id, asambul@unsrat.ac.id
}

\begin{abstract}
Abstrak - Pariwisata adalah sebuah kegiatan atau aktivitas kompleks yang dilakukan berkali-kali dari satu tempat ke tempat lain yang hanya bersifat sementara (tidak menetap) dengan tujuan mendapatkan informasi objek serta mencari kepuasan atau kesenangan dari keindahan objek dan alam sekitarnya. Wisatawan adalah orang-orang yang melakukan kegiatan wisata (UU No. 10 Tahun 2009) yang tertarik dari keindahan alam yang ada di Indonesia khususnya kota Manado yang dikenal sebagai kota pariwisata, akan tapi karena kurangnya pengetahuan mengenai lokasi objek wisata dan bahasa yang digunakan membuat wisatawan kesulitan dalam mencari lokasi dan informasi objek. Tujuan dari penelitian ini adalah membangun sebuah aplikasi berbasis lokasi dan $Q R$ Code yang bertujuan untuk membantu wisatawan dalam melakukan perjalanan wisata ke Manado untuk mencari informasi lokasi objek wisata yang ingin dikunjungi. Aplikasi Android ini diberi nama "Aplikasi Tourism". Dalam aplikasi ini pengguna dapat melihat objek pada peta yang sudah ditandai dengan marker dan melakukan scan pada $Q R$ Code untuk mendapat informasi dengan bahasa yang dapat dimengerti.
\end{abstract}

Kata Kunci: Aplikasi Mobile, Location-Based Service, Pariwisata, QR Code.

Abstract - Tourism is a complex activity or activity that is carried out repeatedly from one place to another that is only temporary (not settled) with the aim of obtaining information objects and seek satisfaction or pleasure from the beauty of the object and the natural surroundings. Tourists are people who do tourism activities (Law No. 10 Year 2009) are attracted from the natural beauty of Indonesia, especially the city of Manado known as a tourist city, but because of the lack of knowledge about the location of tourist attractions and the language used to make tourists difficulty in finding location and object information. The purpose of this research is to build a locationbased and QR Code application that aims to assist tourists in travel to Manado to find information on the location of the tourist attraction you want to visit. This Android app is named "Application Tourism". In this application users can view objects on a map that has been marked with markers and scan the QR Code to get information in understandable language.

Keyword: Aplication Mobile, Location-Based Service, QR Code, Tourism.

\section{PENDAHULUAN}

Pariwisata merupakan sebuah kegiatan untuk melakukan perjalanan yang memiliki tujuan untuk berlibur, mencari kepuasan/kesenangan, berkreasi atau menikmati keindahan alam yang dilakukan secara berkelompok dan juga bersifat sementara. Karena hal itu yang menjadi pendorong rasa keingintahuan para wisatawan untuk berkunjung ke tempat-tempat wisata.

Wisatawan adalah orang-orang yang melakukan kegiatan wisata (UU No. 10 Tahun 2009). Wisatawan terbagi menjadi 2 golongan yaitu Nusantara (dalam negri) dan Asing (berasal dari luar negri). Karena banyak objek wisata yang menggunakan bahasa Indonesia, membuat para wisatawan kesulitan ketika mencari informasi tentang objek wisata yang ingin dilihat atau deskripsi dalam bahasa yang tidak dimengerti wisatawan asing.

Location based service (LBS) merupakan suatu sistem yang menyediakan layanan berbasis lokasi dalam mengambil keputusan dimana sistem tersebut merupakan kombinasi dari masyarakat, teknologi informasi dan prosedur-prosedur yang tergorganisasi dan dapat memberikan informasi secara tepat. Sistem informasi yang akan dibuat yaitu Location-based Information berbasis $Q R$ Code untuk tourism.

Quick Response Code merupakan sebuah bentuk evolusi dari kode batang, kode $Q R$ ini dapat menyimpan alamat dan $U R L$, nomor atau teks. $Q R$ Code berfungsi sebagai penghubung secara cepat konten dari dalam jaringan (online) atau luar jaringan (offline). Mengapa memilih kode $Q R$ ? Karena kode bar hanya memiliki max tampung 20 digit sedangkan kode $Q R$ bisa menyimpan ratusan data, artinya kode $Q R$ ini memiliki kapasitas lebih banyak jika dibandingkan dengar bar kode. Selain itu kode $Q R$ ini memiliki keamanan yang jauh lebih baik dari kode bar, dan juga kode $Q R$ ini masih bisa dibaca walau sudah rusak atau robek dengan maksimum tinkat kerusakan $30 \%$. 
Keindahan objek wisata menjadi salah satu alasan yang membuat para wisatawan yang berasal dari dalam maupun luar negri tertarik untuk datang berkunjung ke tempat-tempat wisata, tetapi kurangnya informasi mengenai lokasi objek wisata dan informasinya membuat para wisatawan kesulitan dalam mencari informasi mengenai objek wisata yang dilihat. Oleh karena itu dibutuhkan sebuah sistem informasi yang digunakan dalam QRcode supaya dapat membantu para wisatawan untuk memudahkan perjalanan dalam mencari informasi objek wisata yang ingin mereka kunjungi.

\section{A. Location-Based Service}

Location Based Service (LBS) atau layanan berbasis lokasi dapat didefinisikan sebagai layanan yang mengintegrasikan lokasi atau posisi perangkat seluler dengan informasi lain sehingga memberikan nilai tambah bagi pengguna Layanan lokasi memiliki tradisi panjang. Sejak tahun 1970-an, Departemen Pertahanan AS telah mengoperasikan sistem penentuan posisi global (GPS), infrastruktur satelit yang melayani pemosisian orang dan benda. Awalnya, GPS dirancang untuk tujuan militer, tetapi pemerintah AS memutuskan pada tahun 1980 untuk membuat data posisi sistem tersedia secara gratis untuk industri lain di seluruh dunia [5]. Terdapat 2 unseur utama dalam LBS ini yaitu:

\section{Location Manager (API Maps)}

Menyediakan tools/resource untuk LBS, Application Programming Interface (API) Maps menyediakan fasilitas untuk menampilkan, memanipulasi peta beserta feature-feature lainnya seperti tampilan satelit, street (jalan), maupun gabungannya. Paket ini berada pada com.google.android.maps.

\section{Location Providers (API Location)}

Menyediakan teknologi pencarian lokasi yang digunakan oleh device. API Location berhubungan dengan data GPS dan data lokasi real-time. API Location berada pada paket Android yaitu dalam paket android.location. Dengan Location Manager, kita dapat menentukan lokasi kita saat ini, Track perpindahan, serta kedekatan dengan lokasi tertentu dengan mendeteksi perpindahan [4].

\section{B. QR Code}

$Q R$ Code diciptakan oleh Denzo Wave pada tahun 1994 dari Jepang. Pada awal pembuatan kode $Q R$ digunakan untuk mendata sparepart kendaraan dalam perusahaannya yaitu Denzo Corporation yang masih bagian dari Toyota Group. Tujuan dari kode $Q R$ ini adalah untuk menyampaikan informasi secara cepat dan juga mendapat tanggapan secara cepat. Kode $Q R$ ini perkembangan dari Barcode atau kode batang yang hanya mampu menyimpan informasi secara horizontal sedangkan kode $Q R$ mampu menyimpan informasi lebih banyak, baik secara horizontal maupun vertical [6].

Kode $Q R$ memiliki kapasitas tinggi dalam data pengkodean, yaitu mampu menyimpan semua jenis data, seperti data numerik, data alphabetis, kanji, katakana, hiragana, simbol, dan kode biner. Secara spesifik, kode $Q R$ mampu menyimpan data jenis numerik sampai dengan 7.089 karakter, data alphanumerik sampai dengan 4.296 karakter, kode binari sampai dengan 2.844 byte, dan huruf kanji sampai dengan 1.817 karakter. Selain itu kode $Q R$ memiliki tampilan yang lebih kecil daripada kode batang. Hal ini dikarenakan kode $Q R$ mampu menampung data secara horizontal dan vertikal, oleh karena itu secara otomatis ukuran dari tampilannya gambar kode $Q R$ bisa hanya seperspuluh dari ukuran sebuah kode batang.

Kode $Q R$ juga tahan terhadap kerusakan, sebab kode $Q R$ mampu memperbaiki kesalahan sampai dengan $30 \%$. Oleh karena itu, walaupun sebagian simbol kode $Q R$ kotor ataupun rusak, data tetap dapat disimpan dan dibaca. Tiga tanda berbentuk persegi di tiga sudut memiliki fungsi agar simbol dapat dibaca dengan hasil yang sama dari sudut manapun sepanjang 360 derajat. Kode $Q R$ biasanya berbentuk persegi putih kecil dengan bentuk geometris hitam, meskipun sekarang banyak yang telah berwarna dan digunakan sebagai brand produk [1].

\section{Android}

Android merupakan Sistem Operasi berbasis Linux yang digunakan untuk smartphone dan juga tablet. Android bersifat open source dan juga Android menyediakan platform terbuka bagi para pengembang untuk menciptakan atau mengembangkan aplikasi mereka sendiri. Android didirikan oleh Andy Rubin, Rich Miner, Nick Sears dan Chris White pada tahun 2003, dan pada tahun 2005 diambil alih keseluruhannya oleh google. Android memiliki sifat yang open source dan bebas untuk dikembangkan oleh developer smartphone hal tersebut membuat sistem operasi ini menjadi sangat populer hingga menjadi nomor satu di dunia mengalakan sistem operasi dari Microsoft dan iOS [2].

\section{Model Prototype}

Menurut Roger S. Pressman, Model Prototipe terdapat empat tahap pengembangan perangkat lunak yang membuat suatu prototype sebagai alat untuk mengetahui lebih jelas tentang kebutuhan dari para pengguna dan juga bisa memungkinkan para pengembang perangkat lunak untuk lebih memahami kebutuhan apa yang akan 
dikerjakan pada interaksi selanjutnya. Dalam pengembangan suatu perangkat lunak yaitu [3]:

\section{Komunikasi.}

Komunikasi merupakan tahap awal dimana pengembang melakukan komunikasi dengan para stakeholder untuk mendapatkan spesifikasi kebutuhan.

2. Perancangan dan pemodelan cepat.

Pada tahap kedua ini dilakukan sebuah perancangan dan pemodelan rancangan spesifikasi yang di dapat dari tahap komunikasi dengan para stakeholder.

3. Pembentukan Prototype.

Tahap pembentukan prototype ini dilakukan setelah mendapat hasil dari perancangan dan pemodelan untuk memulai konstruksi dari pembuatan prototype

4. Penyerahan Sistem dan Umpan Balik.

Tahapan ini merupakan tahapan terakhir dimana pengembang akan melakukan penyerahan perangkat lunak dan kemudian menerima umpan balik.

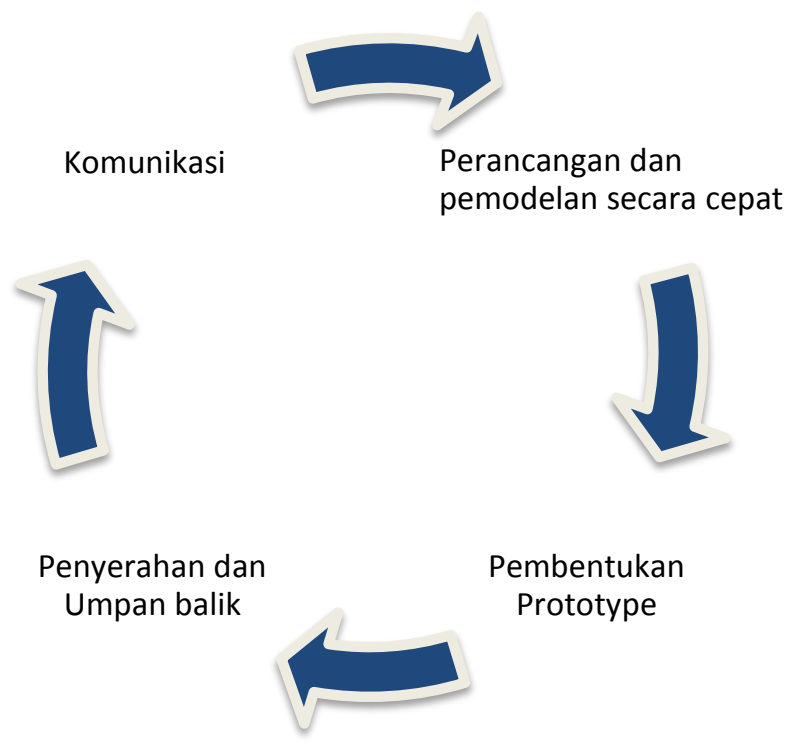

Gambar 1 Model Prototipe

Pada gambar 1 dapat dilihat sebuah pengembangan perangkat lunak yang di lakukan yaitu komunikasi antara pengembang perangkat lunak dengan pengguna. Interaksi pembuatan prototipe direncanakan dengan cepat dan pemodelan dilakukan dalam bentuk rancangan cepat. Kemudian memulai konstruksi pembuatan prototipe. Prototipe kemudian diserahkan pada pengguna dan menerima umpan balik dari pengguna

\section{METODOLOGI PENELITIAN}

\section{A. Kerangka Penelitian}

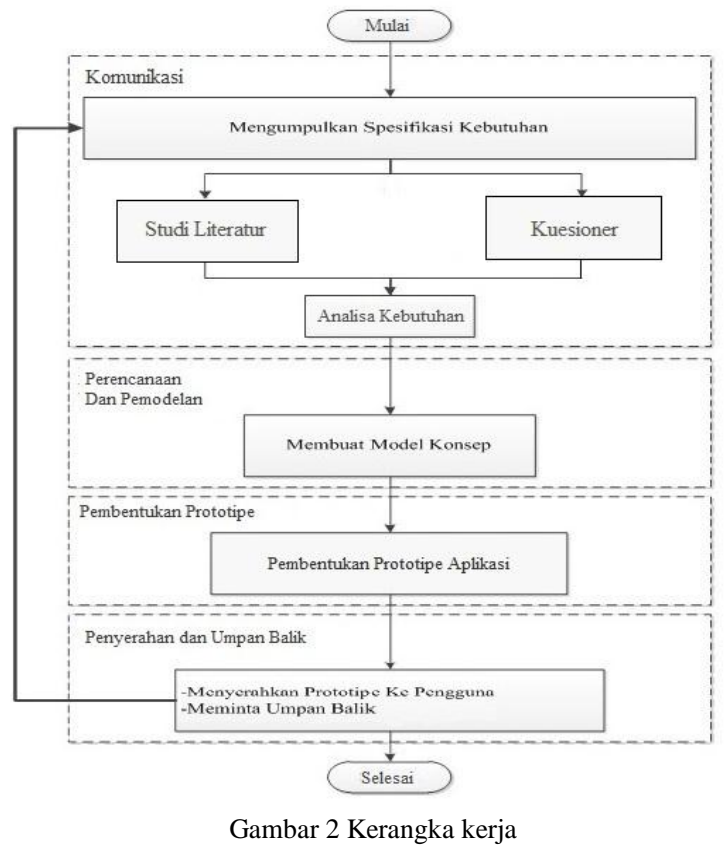

Sebelum pembuatan perangkat lunak dibuat, hal yang dilakukan pembuat adalah membuat kerangka kerja seperti gambar 2 diatas. Tujuan kerangka kerja ini adalah untuk memudahkan pembuat dalam membuat aplikasi.

\section{B. Komunikasi}

Dalam komunikasi, hal yang harus dilakukan adalah mengumpulkan spesifikasi kebutuhan. Terdapat 2 tahap yang dilakukan dalam pengumpulan spesifikasi kebutuhan:

\section{Studi Literatur}

Studi Literatur merupakan sebuah teknik mencari data dengan media buku pembelajaran paper riset atau penelitian-penelitian sebelumnya yang berhubungan dengan proses pembuatan perangkat lunak.

2. Kuesioner

Merupakan teknik pengambilan data dengan cara memberikan pertanyaan tanya jawab kepada masyarakat. Pengambilan data yang dilakukan hanya berupa sebuah kuesioner yang di bagikan kepada masyarakat dengan jumlah 30 sampel.

\section{Perancangan dan Pemodelan}

\section{Use Case Diagram}

Use Case Diagram adalah diagram yang menjelaskan proses kerja secara visual yang mewakili interaksi antara pengguna dengan suatu sistem dari perangkat lunak dengan pengguna sebagai actor, dan case sebagai sistem. 


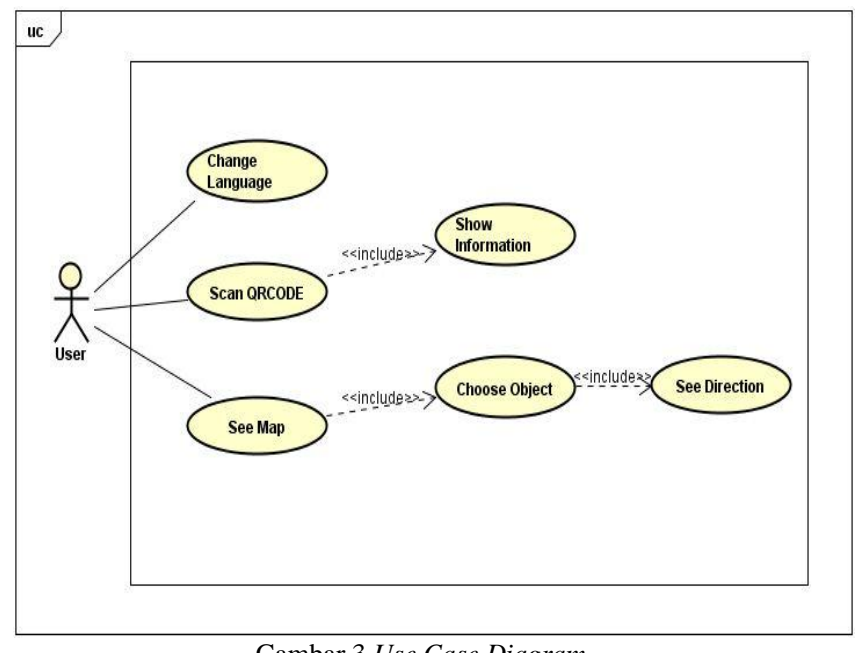

Gambar 3 Use Case Diagram

\section{Activity Diagram}

Activity Diagram adalah diagram yang menunjukan alur kendali dari aktivitas komputasional yang terlibat dalam melakukan kalkulasi atau alur kerja. Sebuah aksi adalah langkah komputasional yang primitive.

a. Gambar 4 menunjukan sebuah aktivitas aplikasi dimana pengguna dapat mengganti bahasa. Terdapat 3 bahasa yang dapat digunakan dalam aplikasi yaitu Bahasa Indonesia, Bahasa Inggris, dan Bahasa Mandarin.

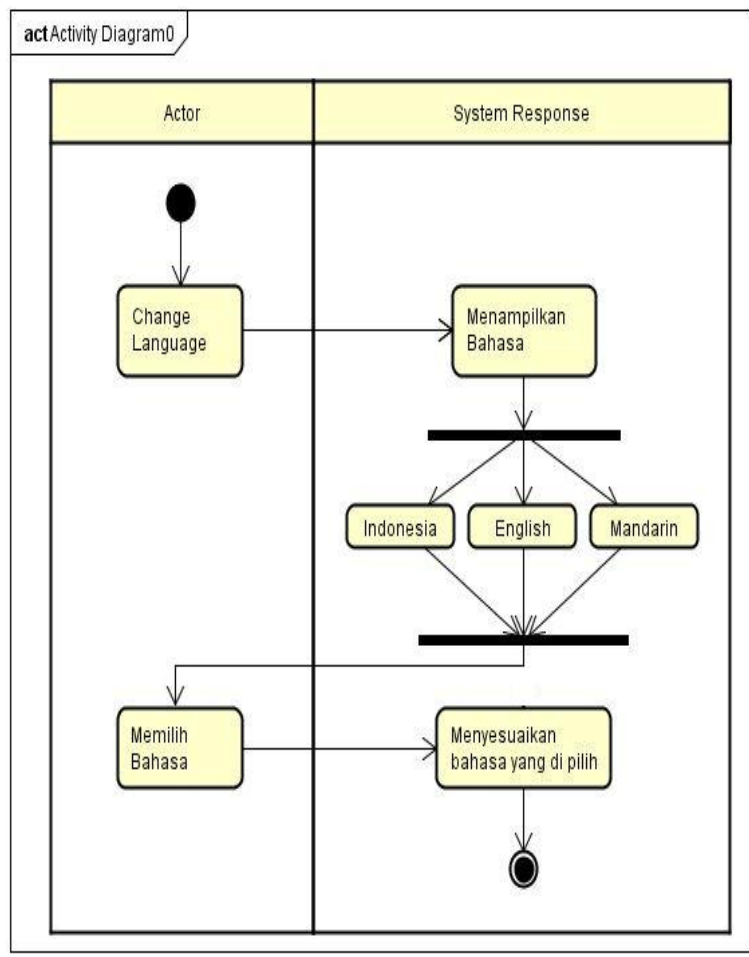

Gambar 4 Activity Ganti Bahasa

b. Gambar 5 menjelaskan bahwa pengguna dapat melakukan scan untuk mendapatkan informasi.

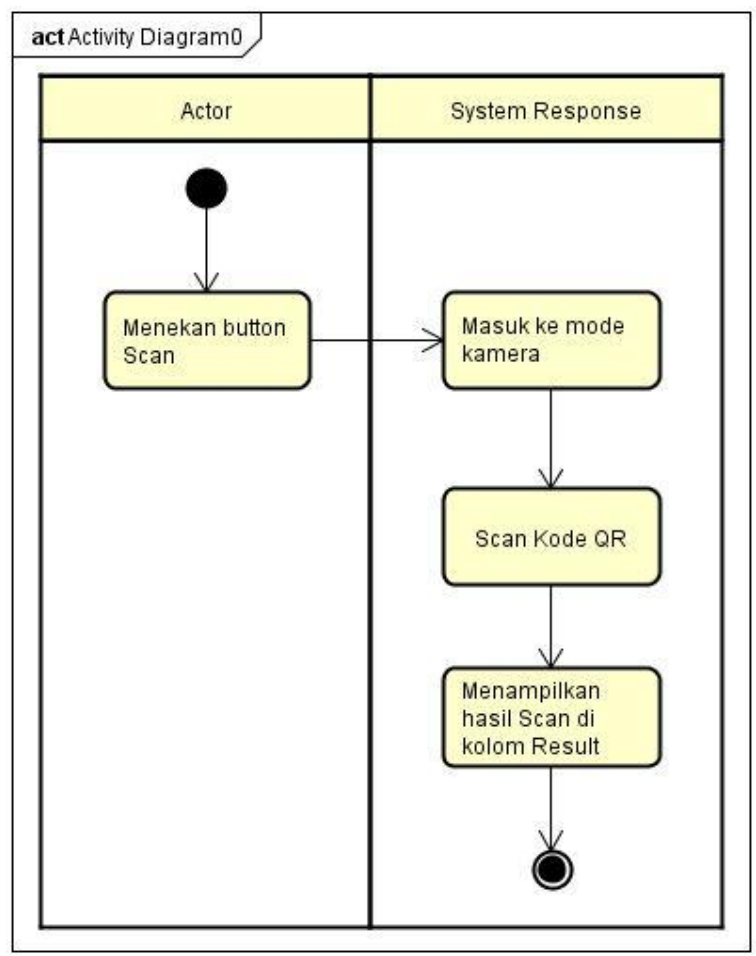

Gambar 5 Activity Scan

c. Gambar 6 menjelaskan pengguna dapat mengakses peta untuk mencari objek wisata yang sudah di tandai dengan marker yang dapat dilihat pada tampilan awal aplikasi. Pengguna juga dapat menekan tombola rah dan aplikasi akan menunjukan arah menuju ke lokasi.

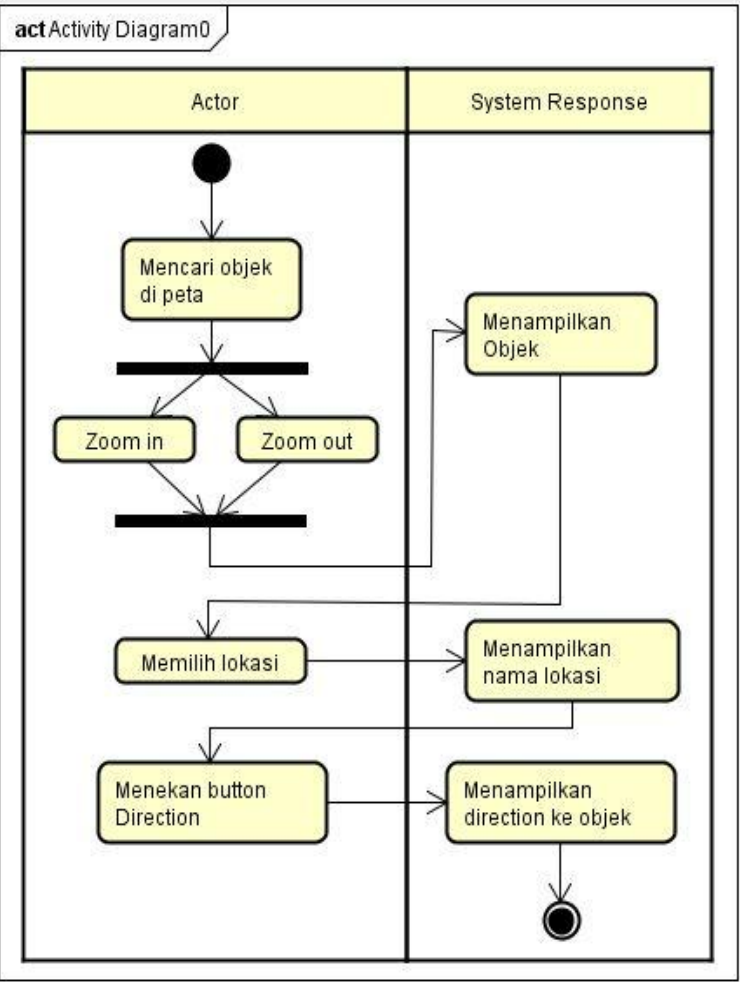

Gambar 6 Activity Map 


\section{Membuat Model konsep}

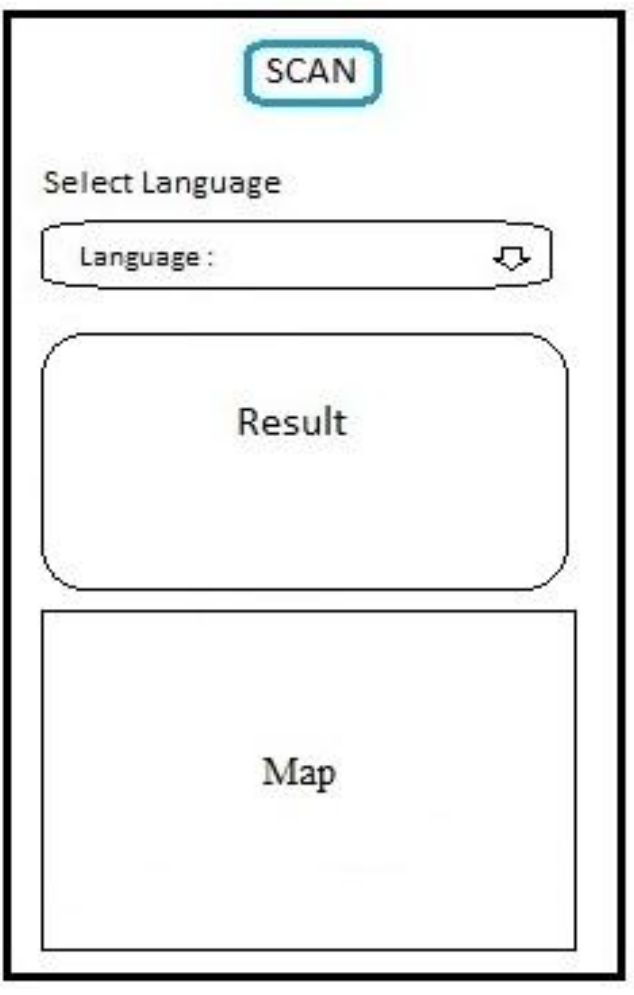

Gambar 7 Tampilan Awal Aplikasi

Penjelasan dari gambar 7 merupakan rancangan model atau tampilan awal dari aplikasi berikut ini merupakan penjelasan dari tampilan awal aplikasi:

a. Button SCAN merupakan kunci utama dalam aplikasi ini yang menghubungkan aplikasi dengan kamera sehingga kamera dapat membaca QRcode lalu menampilkannya di kolom result.

b. Kolom language memungkinkan user supaya bisa mengganti bahasa yang dapat di mengerti, dalam kasus ini bahasa yang tersedia hanya Indonesia, English, dan Mandarin.

c. Kolom Result merupakan hasil dari Scan. Kolom result ini akan menampilkan informasi dari hasil scan. Hasil scan yang di maksud adalah sebuah QRcode yang memuat informasi objek wisata.

d. Kolom Map membuat user dapat melihat lokasi objek wisata yang sudah ditandai dalam peta.

\section{HASIL DAN PENGUJIAN}

\section{A. Hasil Akhir Aplikasi}

1. Gambar 8 merupakan gambar tampilan aplikasi yang sudah selesai dibuat dengan tombol Scan, ganti bahasa, kolom result dan peta yang sudah ada tanda objek wisata.

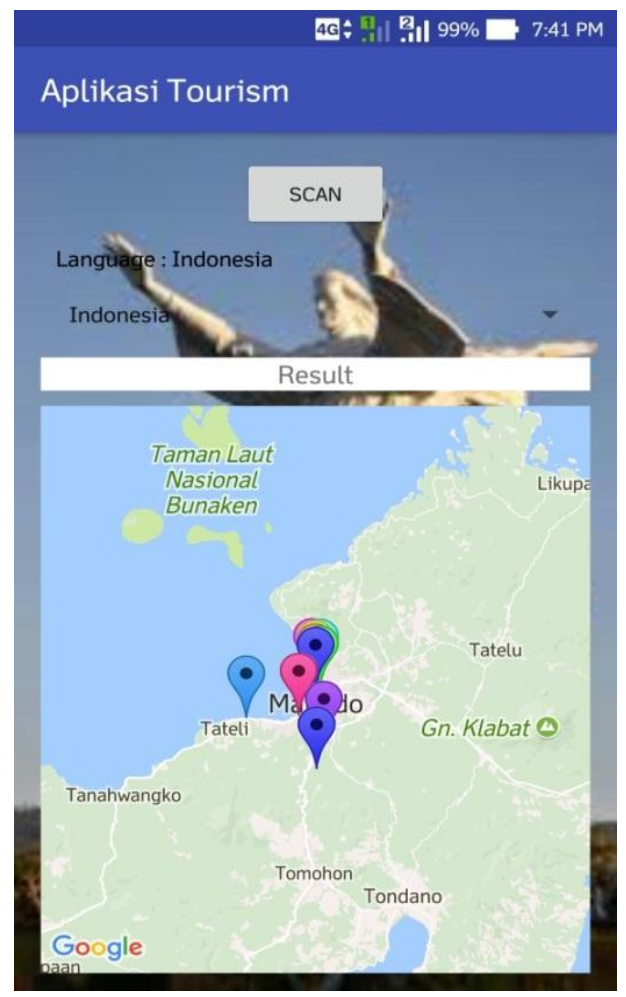

Gambar 8 Tampilan Awal Aplikasi

2. Pada Gambar 9 merupakan hasil dimana pengguna yang sudah memilih objek lalu menekan button arah maka tampilan akan terlihat seperti gambar dibawah.

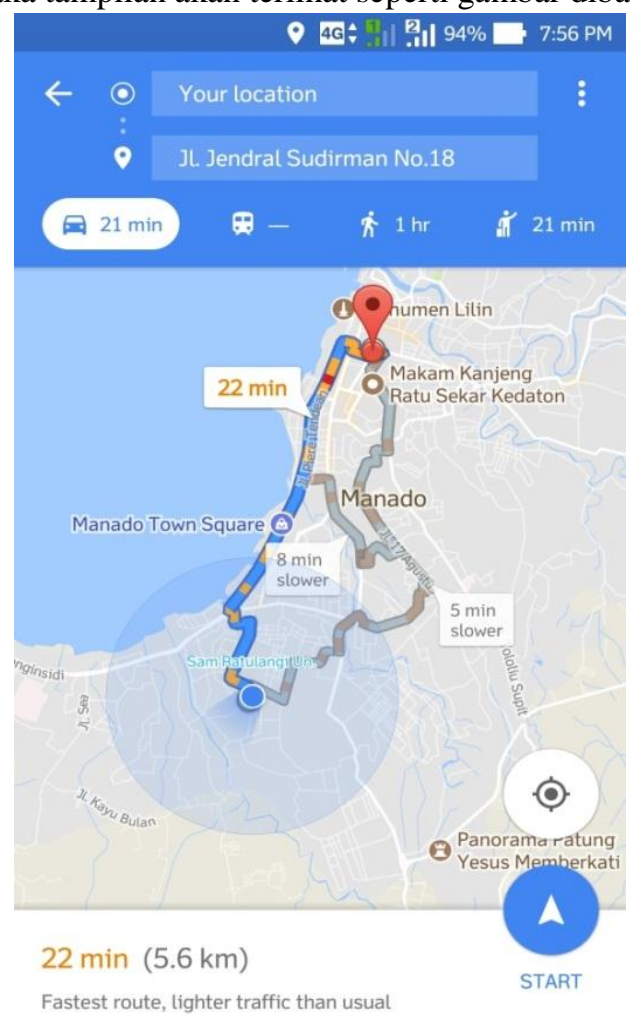

Gambar 9 Tampilan Arah 
3. Gambar 10 merupakan gambar saat aplikasi yang sudah memasuki mode kamera saat pengguna menekan button scan. Pada mode ini aplikasi siap untuk menangkap kode $Q R$ dan menampilkan hasil di kolom result.

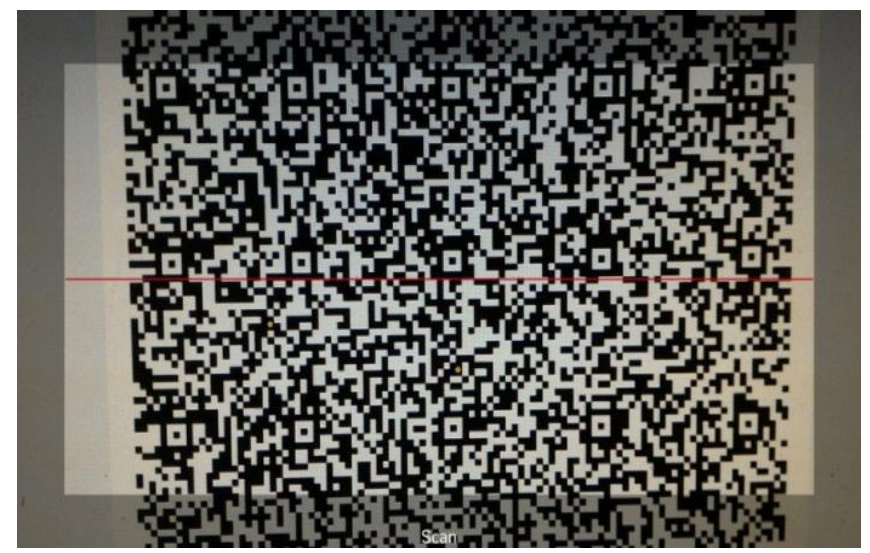

Gambar 10 Tampilan Kamera

4. Gambar 11 merupakan hasil scan dari kode $Q R$ yang di sajikan dalam Bahasa Indonesia.

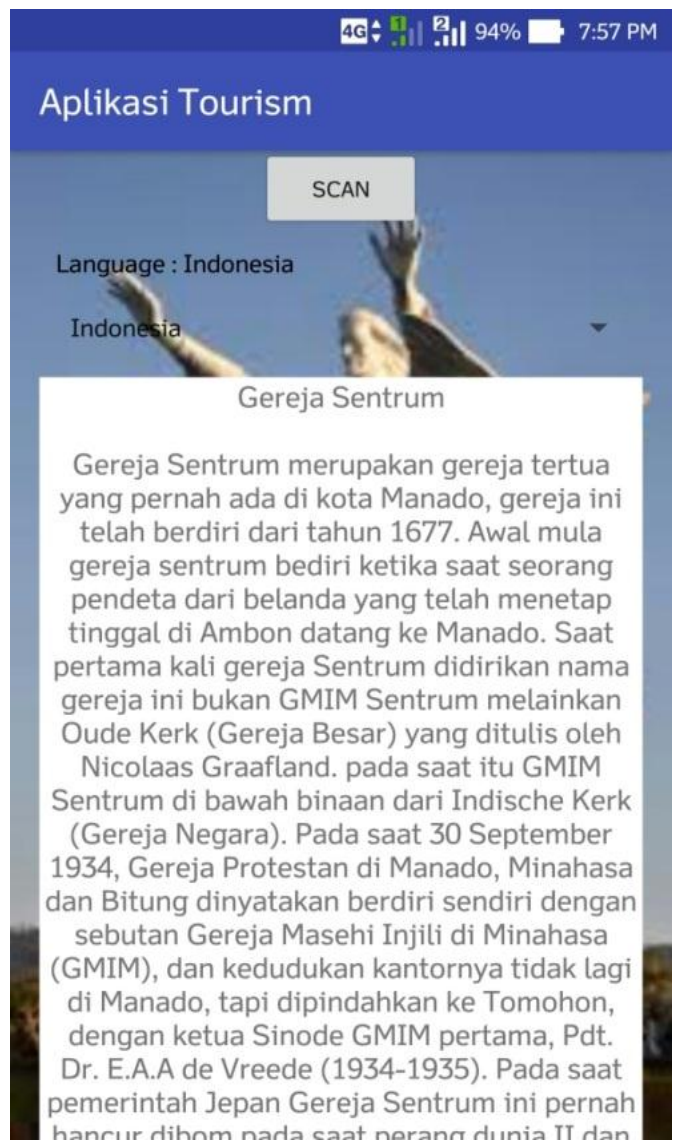

Gambar 11 Tampilan Bahasa Indonesia

5. Gambar 12 merupakan hasil scan dari kode $Q R$ yang di sajikan dalam Bahasa Inggris.

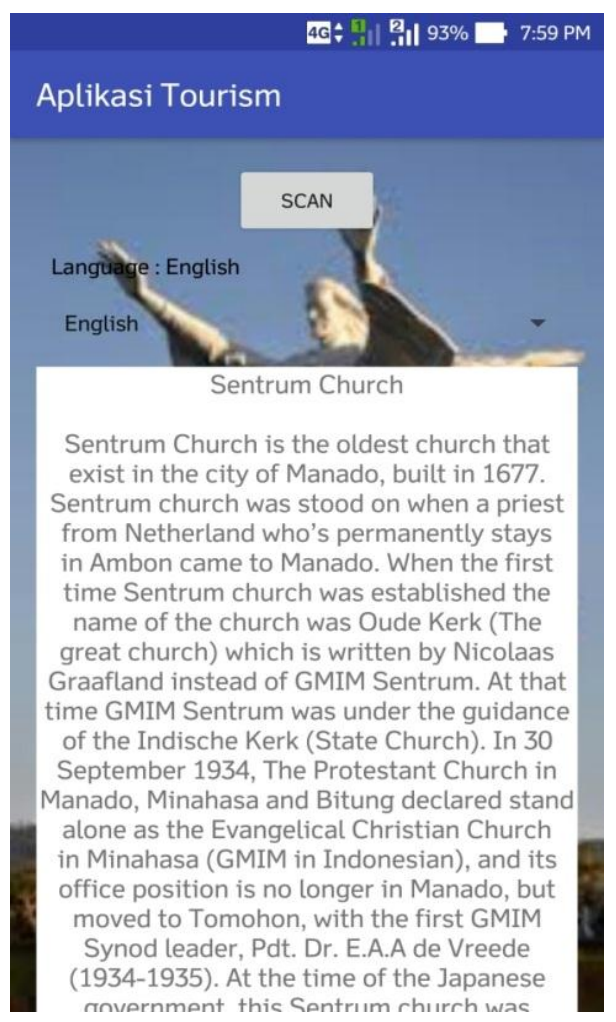

Gambar 12 Tampilan Bahasa Inggris

6. Gambar 13 merupakan hasil scan dari kode $Q R$ yang di sajikan dalam Bahasa Mandarin

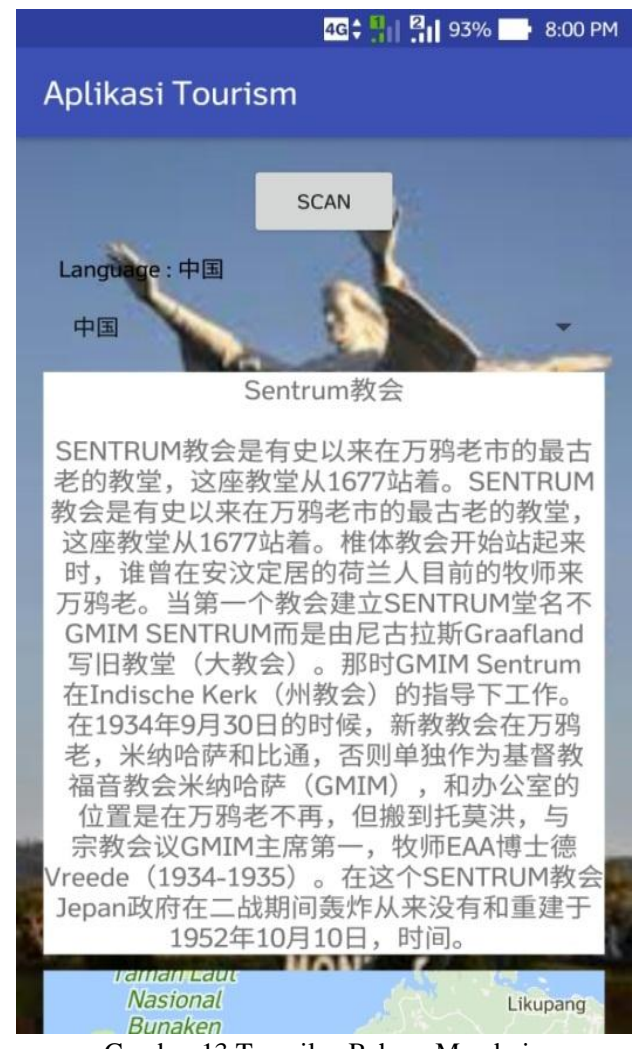

Gambar 13 Tampilan Bahasa Mandarin 
Pada gambar 11, 12, dan 13 merupakan tampilan informasi dalam 3 bahasa berdasarkan hasil scan yang dimuat dalam kolom hasil.

\section{B. Pengujian}

Pengujian aplikasi dilakukan dengan menggunakan 3 buah mobile dengan sistem operasi yang berbeda dan juga 3 kriteria yang diuji yaitu pencahayaan dari gelap, terang dan silau.

\section{Zenfone 2 (OS: Marshmallow)}

Tabel 1 Percobaan Menggunakan Zenfone 2

\begin{tabular}{|c|c|c|c|}
\hline $\begin{array}{c}\text { Pengujian } \\
\text { Pencahayaan }\end{array}$ & $\begin{array}{c}\text { Jarak } \\
\text { (meter) }\end{array}$ & $\begin{array}{c}\text { Waktu } \\
\text { Mendeteksi } \\
\text { (Detik) }\end{array}$ & Keterangan \\
\hline \multirow{3}{*}{ Gelap } & 1 meter & $2-4$ & $\begin{array}{l}\text { Menyesuaikan } \\
\text { pada auto } \\
\text { focus kamera }\end{array}$ \\
\hline & 3 meter & $3-7$ & $\begin{array}{c}\text { Menyesuaikan } \\
\text { pada auto } \\
\text { focus kamera }\end{array}$ \\
\hline & 5 meter & - & $\begin{array}{c}\text { Kamera tidak } \\
\text { dapat } \\
\text { membaca kode } \\
Q R\end{array}$ \\
\hline \multirow{3}{*}{ Terang } & 1 meter & $1-3$ & $\begin{array}{l}\text { Menyesuaikan } \\
\text { pada auto } \\
\text { focus kamera }\end{array}$ \\
\hline & 3 meter & $2-4$ & $\begin{array}{c}\text { Menyesuaikan } \\
\text { pada auto } \\
\text { focus kamera }\end{array}$ \\
\hline & 5 meter & $6-20$ & $\begin{array}{l}\text { Menyesuaikan } \\
\text { pada auto } \\
\text { focus kamera }\end{array}$ \\
\hline \multirow{3}{*}{ Silau } & 1 meter & - & $\begin{array}{c}\text { Kamera tidak } \\
\text { dapat } \\
\text { membaca kode } \\
Q R\end{array}$ \\
\hline & 3 meter & - & $\begin{array}{c}\text { Kamera tidak } \\
\text { dapat } \\
\text { membaca kode } \\
Q R\end{array}$ \\
\hline & 5 meter & - & $\begin{array}{l}\text { Kamera tidak } \\
\text { dapat } \\
\text { membaca kode } \\
Q R\end{array}$ \\
\hline
\end{tabular}

2. Xiaomi Mi4c (Os: Lolipop)

Tabel 2 Percobaan Menggunakan Xiaomi Mi4c

\begin{tabular}{|c|c|c|c|}
\hline $\begin{array}{c}\text { Pengujian } \\
\text { Pencahayaan }\end{array}$ & $\begin{array}{c}\text { Jarak } \\
\text { (meter) }\end{array}$ & $\begin{array}{c}\text { Waktu } \\
\text { Mendeteksi } \\
\text { (Detik) }\end{array}$ & Keterangan \\
\hline \multirow{3}{*}{ Gelap } & 1 meter & $2-3$ & $\begin{array}{c}\text { Menyesuaikan } \\
\text { pada auto } \\
\text { focus kamera }\end{array}$ \\
\hline & 3 meter & $3-6$ & $\begin{array}{c}\text { Menyesuaikan } \\
\text { pada auto } \\
\text { focus kamera }\end{array}$ \\
\hline & 5 meter & - & $\begin{array}{c}\text { Kamera tidak } \\
\text { dapat } \\
\text { membaca kode } \\
Q R\end{array}$ \\
\hline \multirow{3}{*}{ Terang } & 1 meter & $1-2$ & $\begin{array}{l}\text { Menyesuaikan } \\
\text { pada auto } \\
\text { focus kamera }\end{array}$ \\
\hline & 3 meter & $2-4$ & $\begin{array}{c}\text { Menyesuaikan } \\
\text { pada auto } \\
\text { focus kamera }\end{array}$ \\
\hline & 5 meter & $5-13$ & $\begin{array}{c}\text { Menyesuaikan } \\
\text { pada auto } \\
\text { focus kamera }\end{array}$ \\
\hline \multirow{3}{*}{ Silau } & 1 meter & - & $\begin{array}{c}\text { Kamera tidak } \\
\text { dapat } \\
\text { membaca kode } \\
Q R\end{array}$ \\
\hline & 3 meter & - & $\begin{array}{c}\text { Kamera tidak } \\
\text { dapat } \\
\text { membaca kode } \\
Q R\end{array}$ \\
\hline & 5 meter & - & $\begin{array}{c}\text { Kamera tidak } \\
\text { dapat } \\
\text { membaca kode } \\
Q R\end{array}$ \\
\hline
\end{tabular}

\section{Lenovo A328 (OS: Kitkat)}

Tabel 3 Percobaan Menggunakan Lenovo A328

\begin{tabular}{|cccc|}
\hline $\begin{array}{c}\text { Pengujian } \\
\text { Pencahayaan }\end{array}$ & $\begin{array}{c}\text { Jarak } \\
\text { (meter) }\end{array}$ & $\begin{array}{c}\text { Waktu } \\
\text { Mendeteksi } \\
\text { (Detik) }\end{array}$ & Keterangan \\
\hline
\end{tabular}




\begin{tabular}{|c|c|c|c|}
\hline \multirow{3}{*}{ Gelap } & 1 meter & $4-7$ & $\begin{array}{c}\text { Menyesuaikan } \\
\text { pada auto } \\
\text { focus kamera }\end{array}$ \\
\hline & 3 meter & $5-12$ & $\begin{array}{c}\text { Menyesuaikan } \\
\text { pada auto } \\
\text { focus kamera }\end{array}$ \\
\hline & 5 meter & - & $\begin{array}{c}\text { Kamera tidak } \\
\text { dapat } \\
\text { membaca kode } \\
Q R\end{array}$ \\
\hline \multirow{3}{*}{ Terang } & 1 meter & $2-5$ & $\begin{array}{c}\text { Menyesuaikan } \\
\text { pada auto } \\
\text { focus kamera }\end{array}$ \\
\hline & 3 meter & $4-8$ & $\begin{array}{c}\text { Menyesuaikan } \\
\text { pada auto } \\
\text { focus kamera }\end{array}$ \\
\hline & 5 meter & $9-22$ & $\begin{array}{c}\text { Menyesuaikan } \\
\text { pada auto } \\
\text { focus kamera }\end{array}$ \\
\hline \multirow{3}{*}{ Silau } & $\begin{array}{c}1 \\
\text { meter }\end{array}$ & - & $\begin{array}{c}\text { Kamera tidak } \\
\text { dapat } \\
\text { membaca } \\
\text { kode } Q R\end{array}$ \\
\hline & 3 meter & - & $\begin{array}{c}\text { Kamera tidak } \\
\text { dapat } \\
\text { membaca kode } \\
Q R\end{array}$ \\
\hline & 5 meter & - & $\begin{array}{c}\text { Kamera tidak } \\
\text { dapat } \\
\text { membaca kode } \\
Q R\end{array}$ \\
\hline
\end{tabular}

Pada pengujian aplikasi diatas dapat di tarik kesimpulan bahwa setiap smartphone memiliki perbedaan dalam mendeteksi kode $Q R$. Waktu yang diperlukan untuk mendeteksi kode $Q R$ juga bervariasi, hal ini di karenakan perbedaan pixel pada kamera dan smartphone yang bergerak saat melakukan scan membuat auto focus pada kamera sulit untuk menyesuaikan jarak antara smartphone dengan kode $Q R$ dan memperlambat proses pengambilan data dari kode $Q R$.

\section{Kuesioner Umpan Balik}

Setelah pengujian aplikasi selesai maka dilakukan umpan balik. Umpan balik yang dilakukan pembuat diberikan kepada 30 pengguna. berikut ini adalah contoh sampel yang di ambil secara acak.

\section{Apakah aplikasi tourism ini sudah dapat menjadi alat bantu bagi wisatawan yang datang di Manado?}

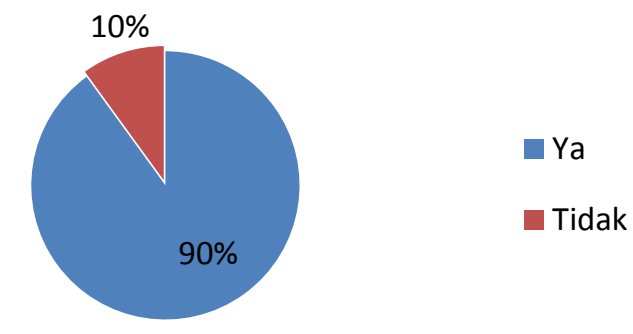

Gambar 14 Hasil Umpan Balik Mengenai Manfaat Aplikasi Tourism

\section{PENUTUP}

\section{A. Kesimpulan}

Berdasarkan hasil pembahasan dari penulisan ini maka dapat di tarik kesimpulan sebagai berikut:

1. Aplikasi informasi lokasi berbasis $Q R$ Code telah berhasil dibuat, dan dapat dijalankan pada platform android untuk membantu wisatawan dalam mencari informasi objek wisata.

2. Hasil dari rancangan prototype aplikasi tourism untuk wisatawan telah berjalan dengan baik dan sesuai dengan rancangan yaitu menampilkan informasi objek wisata dalam 3 bahasa.

3. Rancangan aplikasi ini dapat menjadi solusi yang baik dari permasalahan yang ada, yaitu untuk memberikan informasi lokasi dan objek wisata yang ingin dikunjungi.

\section{B. Saran}

Seperti yang dijelaskan pada kesimpulan diatas bahwa aplikasi $Q R$ Code untuk pariwisata ini masih terdapat banyak kekurangan. Oleh karena itu, berikut ini terdapat beberapa saran yang dapat menjadi pertimbangan untuk peneliti berikut:

1. Memperbanyak kode $Q R$ yang dipasang pada objek wisata di dalam kota Manado.

2. Menambahkan jumlah dan jenis bahasa asing pada objek wisata yang digunakan dalam aplikasi.

3. Dapat memperluas kode $Q R$ pada lokasi objek wisata sampai mencakup seluruh Provinsi Sulawesi Utara. 


\section{TINJAUAN PUSTAKA}

[1] Aktas, C, The Evolution And Emergence Of $Q R$ Codes. Newcastle: Cambridge Scholars, 2017.

[2] Koyuko, H, Perancangan Aplikasi Monitoring Pemadaman Listrik Berbasis Android Studio Kasus PT.PLN Area Manado. Manado: Fakultas Teknik, Universitas Sam Ratulangi, 2016.

[3] Pressman, R. S. Rekaya Perangkat lunak. Yogyakarta: Andi, 2010.

[4] Rompas, B. R, Aplikasi Location-Based Service Pencarian Tempat Di Kota Manado Berbasis Android. Teknik Elektro dan Komputer, 1-11, 2012.

[5] Schiller, J, Location-Based Service. San Francisco: Morgan Kaufmann, 2004.

[6] Sholeh, M. L, Smart Presensi Menggunakan QRCode Dengan Enkripsi VIGENERE. ISSN, 31-44, 2016.

\section{RIWAYAT PENULIS}

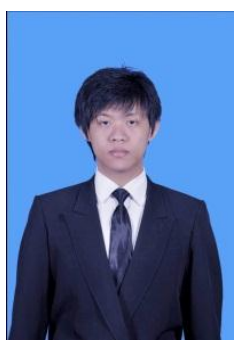

Penulis bernama Vicky Sumendap Gunawan yang merupakan anak pertama dari dua bersaudara dalam keluarga. Lahir di Babang, Maluku Utara, pada tanggal 30 Desember 1994. Sekarang penulis tinggal di Manado, Sulawesi Utara dengan alamat Kleak, Jl. P. Peleng, No 142, Kec. Malalayang, Manado, Sulawesi Utara.

Penulis mulai menempuh pendidikan di Sekolah Dasar GMIM 15 sampai naik kelas 2 (2000-2001) dan kemudian pindah ke Sekolah Dasar Negeri 37 Manado (2001-2006). Setelah itu, penulis melanjutkan pendidikan tingkat pertama ke SMP Negeri 4 Manado (2006-2009). Setelah lulus SMP, penulis melanjutkan pendidikan tingkat akhir ke SMA St. Thomas Aquino Manado (2009-2012).

Setelah lulus dari SMA pada tahun 2012, penulis melanjutkan pendidikan ke salah satu perguruan tinggi yang ada di kota Manado yaitu Universitas Sam Ratulangi Manado. Dengan mengambil Program Studi S-1 Teknik Informatika di jurusan Elektro Fakultas Teknik. 